\title{
La langue, organe clé des oralités/ The tongue, a key organ of oral processes
}

\author{
Comentado por: Fernanda Prada Machado ${ }^{1}$, Maria Claudia Cunha ${ }^{2}$
}

Thibault C. La langue, organe clé des oralités. Rééduc Orthoph. 2006;44(226):115-24.

Rééducation Orthophonique é um periódico com volumes temáticos e o artigo em análise foi publicado num volume cujo tema é a deglutição disfuncional, e vem corroborar com vários estudos recentes sobre o conceito psicanalítico de oralidade, que agrega as dimensões orgânica e simbólica.

A autora, Catherine Thibault, fonoaudióloga e psicóloga, faz parte da equipe do serviço de estomatologia e cirurgia maxilo-facial do Hospital Necker-Enfants Malades em Paris, renomado hospital francês que vem desenvolvendo trabalhos nesta perspectiva.

Aqui a língua é considerada, nas palavras da autora, como órgão chave das oralidades - alimentar e verbal - consideradas como indissociáveis do prazer oral em que se assenta o desenvolvimento neurológico e psíquico da criança.

A premissa da qual parte a autora é a de que a oralidade é constituída pelo conjunto de fenômenos psíquicos, biológicos e funcionais que asseguram a evolução do comportamento oral da criança; no que tange às funções do sistema estomatognático e à linguagem oral.

$\mathrm{O}$ artigo estrutura-se da seguinte forma: trata da oralidade fetal como fundadora do sujeito para, em seguida, abordar as funções pertencentes à oralidade e à esfera orofacial como representantes do entrecruzamento anatômico da palavra e do alimento. Daí emerge a idéia da língua como órgão chave das oralidades.

Quanto ao desenvolvimento fetal, a autora destaca que as primeiras manifestações da oralidade nessa fase são observadas no decorrer do terceiro mês de gestação: com a formação do palato e o rebaixamento da língua (fenômenos típicos dessa etapa embriológica), a mão toca os lábios, a boca se abre e a língua projeta-se para tocar a mão.

Em torno da décima semana, os primeiros movimentos ântero-posteriores de sucção aparecem, para que possa ocorrer a deglutição (entre a $12^{\mathrm{a}}$ e a $15^{\mathrm{a}}$ semanas).

(1) Membro colaborador de projeto da linha de pesquisa Linguagem, Corpo e Psiquismo do Programa de Estudos Pós-graduados em Fonoaudiologia da Pontifícia Universidade Católica de São Paulo - PUC/SP - São Paulo (SP), Brasil.

(2) Docente da Faculdade e do Programa de Estudos Pós-graduados em Fonoaudiologia da Pontifícia Universidade Católica de São Paulo - PUC/SP - São Paulo (SP), Brasil.

Endereço para correspondência: Fernanda Prada Machado. R. Albuquerque Lins, 958/11, Higienópolis, São Paulo - SP, CEP 01230-000. E-mail: femachado@uol.com.br
A esfera orofacial é considerada como alicerce das funções essenciais à sobrevivência, tais como: a respiração, a nutrição (deglutição, mastigação), a relacional e a de expressão (mímica e fonação).

Estes processos, envolvidos nas dimensões do prazer e do desprazer infantil, participam da constituição e do desenvolvimento do psiquismo desde a fase fetal.

Com relação à oralidade alimentar e verbal, a autora chama a atenção para a relação de intimidade que ambas estabelecem entre si, no processo de constituição subjetiva. Nesta perspectiva, é preciso sublinhar que, após o nascimento, a região oral é lugar do primeiro prazer (na amamentação), assim como da primeira expressão de si (o choro).

Vale notar a importância dos diferentes ritmos que se organizam em torno da boca; a alternância saciedade/fome, as repetidas sensações de prazer/desprazer, os movimentos de sucção, entre outros. Esses diferentes ritmos, assim como os maternos, ajudam o bebê a construir sua própria estrutura rítmica e temporal e marcam a constituição da personalidade.

Nessa linha de raciocínio, a autora vai construindo seu argumento, inclusive com base em estudos neurológicos, para re-afirmar que a língua é o órgão chave das oralidades. Segundo ela, nos primeiros momentos do desenvolvimento da oralidade, a língua pode investir livremente em todo o espaço da boca, já que há a predomínio do reflexo de sucção/ deglutição.

$\mathrm{Na}$ seqüência, com o desenvolvimento concomitante e progressivo das oralidades (alimentar e verbal), a língua muda radicalmente de estratégia: com a maturação neurológica, o reflexo de sucção dá progressivamente lugar à um novo gesto no campo gnosopráxico: a língua pode agora "aprender" a comer e a falar.

No decorrer do segundo ano de vida, a mastigação evidencia-se, permitindo que a criança construa a oralidade alimentar; descobrindo novos sabores, texturas, cores e modos de apreensão dos alimentos, ao mesmo tempo em que desenvolve a oralidade verbal - oral.

Nessa perspectiva, a autora conclui afirmando que a língua vai gerir o espaço oral com o refinamento gnoso-práxico que ocorre pela mastigação dos alimentos e pela articulação dos fonemas.

Estudos como este destacam a importância de considerarmos a região oral de nossos pacientes na interface entre linguagem, corpo e psiquismo. Apontam ainda para a estrei- 
ta relação que existe entre o comer e o falar. Tal co-ocorrência, evidenciada pelo trabalho em análise, gera efeitos no aprimoramento do método clínico terapêutico fonoaudiológico, no que diz respeito a procedimentos de avaliação e terapia, numa abordagem bio-psíquica dos problemas de alimentação e de linguagem.

Tal perspectiva teórico-metodológica explicita-se também em trabalhos recentes de fonoaudiólogos brasileiros ${ }^{(1-4)}$.

\section{REFERÊNCIAS}

1. Ferraz AO. E Quando o paciente não quer comer? Um estudo sobre as queixas alimentares de crianças com distúrbios do apetite [tese]. São Paulo: Pontifícia Universidade Católica de São Paulo; 2006.

2. Machado FP. Problemas de linguagem oral e de alimentação: coocorrências na clínica fonoaudiológica [tese]. São Paulo: Pontifícia Universidade Católica de São Paulo; 2007.
3. Magalhães LA. O atendimento fonoaudiológico nas disfagias: do corpoobjeto ao corpo dos afetos [tese]. São Paulo: Pontifícia Universidade Católica de São Paulo; 2007.

4. Palladino RRR, Souza LAP, Cunha MC. Transtornos de linguagem e transtornos alimentares em crianças. Psicanal Univ. 2004;21:95-108. 